\title{
Streptococcus infantarius sp. nov., Streptococcus infantarius subsp. infantarius subsp. nov. and Streptococcus infantarius subsp. coli subsp. nov., isolated from humans and food
}

\author{
Laurent Schlegel, ${ }^{1,2}$ Francine Grimont, ${ }^{2}$ Matthew D. Collins, ${ }^{3}$ \\ Béatrice Régnault, ${ }^{2}$ Patrick A. D. Grimont ${ }^{2}$ and Anne Bouvet ${ }^{1}$
} Author for correspondence: Anne Bouvet. Tel: + 331423482 73. Fax: + 33142348634.
e-mail: anne.bouvet@htd.ap-hop-paris.fr

1 Centre National de Référence des Streptocoques, Service de Microbiologie, Hôtel Dieu, Université Paris VI, 1 place du Parvis Notre-Dame, F-75181 Paris 04, France

2 Unité des Entérobactéries, INSERM U389, Institut Pasteur, Paris, France

3 Institute of Food Science and Research, University of Reading, Reading, UK

\begin{abstract}
Eighteen strains isolated from human specimens or from food products were characterized as atypical variants of mannitol-negative Streptococcus bovis. They were tested for extended biochemical criteria, ribotyping and DNA-DNA hybridization in order to define their taxonomic status. These strains were demonstrated to constitute a DNA relatedness group that includes strains of DNA group 4 of Farrow et al. (1984). Comparative analysis of 16S rRNA sequences demonstrated that these strains represent a new species which belongs to the Streptococcus bovis/Streptococcus equinus complex and which has been provisionally named S. infantarius by Bouvet et al. (1997). Biotyping and ribotyping allowed differentiation of these strains from the aesculinpositive strains of $S$. bovis belonging to the previously described biotypes $\mathbf{I}$, II.1 and II.2. The results of the ribotyping and hybridization assays demonstrated the presence of two different DNA subgroups within the 18 strains. On the basis of these data, the names $S$. infantarius subsp. infantarius (aesculin-negative for five strains out of seven, including the type strain HDP

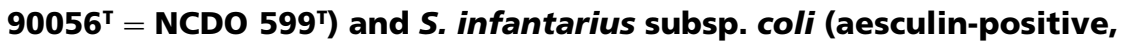
reference strain HDP $90248=$ NCDO 2620) are proposed as the names for these two subspecies within the $S$. infantarius species.
\end{abstract}

Keywords: Streptococcus bovis, Streptococcus infantarius, ribotyping, DNA-DNA hybridization, $16 \mathrm{~S}$ rRNA gene

\section{INTRODUCTION}

Since the delineation of the genus Enterococcus from the non-enterococcal strains of the Streptococcus bovis/Streptococcus equinus complex (Schleifer \& Kilpper-Bälz, 1984), the classification of the group D streptococci has progressively changed according to the descriptions of additional species (Bouvet et al., 1997; Farrow et al., 1984; Osawa et al., 1995; Tsakalidou et al., 1998). Isolates are commonly identified by their ability to grow in the presence of bile, by the inhibition of growth at $\mathrm{pH} 9.6$ or in a hypertonic broth and by the presence of the Lancefield

The GenBank accession number for the sequence of the 16S rRNA gene determined in this study is AF177729. group $\mathrm{D}$ antigen, associated with the production of $\beta$ glucosidase leading to hydrolysis of aesculin (Edberg et al., 1985; Facklam, 1972; Ruoff et al., 1984, 1989). The initial delineation of $S$. bovis and S. equinus strains was based on the ability or inability to produce $\alpha$ galactosidase and to hydrolyse lactose or raffinose (Bridge \& Sneath, 1983; Facklam, 1972; Garvie \& Bramley, 1979; Hardie, 1986; Jones et al., 1972). These differences were also correlated with different host specificity: S. equinus strains were isolated from horses, whereas $S$. bovis is known as a major causative agent of bovine mastitis and was also isolated from human specimens including the faeces of $10 \%$ of healthy humans (Facklam, 1972; Garvie \& Bramley, 1979; Hardie, 1986; Klein et al., 1977; Nelms et al., 1995; Ruoff et al., 1989). 
Phenotypic characterization leads to a classification of $S$. bovis strains based on their biotype. Biotype I designates mannitol-positive strains, whereas biotype II designates mannitol-negative strains. The strains of biotype II.1 ferment starch, melibiose and glycogen, but not trehalose; they do not produce $\beta$-glucuronidase or $\beta$-galactosidase (Coykendall \& Gustafson, 1985; Garvie \& Bramley, 1979; Garvie \& Farrow, 1981). The strains of biotype II.2 ferment trehalose, but not starch or glycogen; they produce $\beta$ glucuronidase and $\beta$-galactosidase (Coykendall \& Gustafson, 1985; Knight \& Shlaes, 1985). This terminology is commonly used for the identification of clinical strains (Ruoff et al., 1989).

Genotypic characterization has led to a reappraisal of this classification and six genomic groups have been described by Farrow et al. (1984). The type strains of $S$. bovis and of $S$. equinus both belong to genomic group 1 (Farrow et al., 1984; Kilpper-Bälz et al., 1982; Nelms et al., 1995), which mainly includes mannitol-negative $S$. bovis biotype II.1 strains of bovine origin. Genomic group 2 has been identified as a new species, called Streptococcus gallolyticus (Osawa et al., 1995). This species includes the strains formerly identified as $S$. bovis biotype I. Most of the mannitolpositive group D streptococci isolated from blood, which are responsible for human endocarditis associated with colonic cancer, might be reclassified in this species (Klein et al., 1977; Nelms et al., 1995; Osawa et al., 1995; Ruoff et al., 1989). Rare atypical mannitol-positive or -negative strains of $S$. bovis/ S. equinus were identified by Farrow et al. (1984) as strains of genomic group 3. Genomic group 4 is heterogeneous (Farrow et al., 1984). It includes both strains sharing an unusual character (the absence of hydrolysis of aesculin) and aesculin-positive strains of human origin associated with a biotype II.1-related biochemical pattern. The level of chromosomal DNA hybridization confirmed that the aesculin-negative strains correspond to an individual species, designated as Streptococcus infantarius (Bouvet et al., 1997). Preliminary investigations of the strains that hydrolysed aesculin have suggested their close relationships with this new species. Genomic groups 5 and 6 of Farrow et al. (1984) include mannitol-positive strains; they have been identified as two new species, named Enterococcus saccharolyticus and Streptococcus alactolyticus, respectively (Farrow et al., 1984; Rodriguez \& Collins, 1990). Recently, a new species named Streptococcus macedonicus has been described from mannitolnegative and aesculin-negative strains (Tsakalidou et al., 1998).

In the present study, 18 strains of $S$. infantarius (previously identified as $S$. bovis biotype II.1) were analysed and compared with strains of $S$. bovis biotype II.2 and with representative strains of the DNA homology groups of the $S$. bovis/S. equinus complex. We demonstrate the existence of two distinct subspecies within the novel species $S$. infantarius, for which we propose the names $S$. infantarius subsp. infantarius ( $\beta$-glucosidase- and aesculin-variable) and $S$. infantarius subsp. coli ( $\beta$-glucosidase- and aesculinpositive).

\section{METHODS}

Strains. Eighteen $S$. bovis biotype II.1 strains were compared with representative strains of the different DNA homology groups defined by Farrow et al. (1984) and with $S$. gallolyticus, S. alactolyticus, E. saccharolyticus and the recently described $S$. macedonicus. The 40 strains examined are listed in Table 1, together with their former identifications according to the phenotypic and genotypic studies. These strains were obtained from the bioMérieux collection of bacteria (bioMérieux, La Balme-les-Grottes, France), the Australian Collection of Microorganisms (ACM, University of Queensland, St Lucia, Australia), the Collection de l'Institut Pasteur (CIP, Institut Pasteur, Paris, France), the Laboratorium voor Microbiology of Gent Culture Collection (LMG, University of Ghent, Belgium), the National Collection of Food Bacteria (NCDO/NCFB, Aberdeen, UK) and from our collection of French National Reference Centre for Streptococci (HDP, Hôtel-Dieu, Paris, France). Cultures were stored at $-80{ }^{\circ} \mathrm{C}$ in brain-heart infusion broth supplemented with $15 \%$ (w/v) glycerol. Subculturing was performed on blood Columbia agar (bioMérieux) or in buffered dextrose broth (Sanofi-Diagnostics Pasteur).

Phenotypic characteristics. The strains were characterized for their morphology, their growth and their biochemical properties. The production of acetoin, enzymic reactions and fermentation of carbohydrates were determined using API 20 STREP and the Rapid ID32 STREP system (Facklam et al., 1984; Freney et al., 1992) according to the manufacturer's instructions (bioMérieux). All strains were cultured on agar plates supplemented with $40 \%$ bile/ aesculin, $5 \%$ sucrose or $0.04 \%$ tellurite sodium. Growth was tested in broth containing 6.5\% (w/v) $\mathrm{NaCl}$ (SanofiDiagnostics Pasteur) and gas production was assayed in MRS broth (Sanofi-Diagnostics Pasteur). Isolates were agglutinated for the Lancefield group D antigen with a latex bead agglutination reagent after enzymic lysis at $37^{\circ} \mathrm{C}$ for 30 min (Pastorex; Sanofi-Diagnostics Pasteur).

Preparation of DNA. Bacteria were grown in 1.51 buffered dextrose broth for $5-7 \mathrm{~h}$ to the mid-exponential phase at $37^{\circ} \mathrm{C}$. Glycine (Sigma) was added to a final concentration of $30 \mathrm{~g}^{-1}$ and incubation was prolonged for an additional hour. Bacteria were then harvested by centrifugation, washed in TE buffer (10 mM Tris, $1 \mathrm{mM} \mathrm{Na}_{2}$ EDTA, pH 8.0) and suspended in lysis buffer ( $10 \mathrm{mM}$ Tris, $1 \mathrm{mM} \mathrm{Na}{ }_{2}$ EDTA, $1 \mathrm{M}$ sucrose, $\mathrm{pH} 8 \cdot 0)$. Mutanolysine (5 U ml-1; Sigma) and lysozyme $\left(10 \mathrm{mg} \mathrm{ml}^{-1}\right.$; Boehringer Mannheim) were added and the mixture was incubated overnight at $37^{\circ} \mathrm{C}$ (Bentley \& Leigh, 1995; Bentley et al., 1991; Grimont \& Grimont, 1995). Bacterial membrane disruption was then achieved with proteinase $\mathrm{K}\left(0.4 \mathrm{mg} \mathrm{ml}^{-1}\right)$ and $\operatorname{SDS}(1 \%, \mathrm{w} / \mathrm{v})$. Sometimes, overnight incubation of the mixture at $37^{\circ} \mathrm{C}$ was necessary for extended lysis. Genomic DNA was extracted and purified using the phenol/chloroform method of Brenner et al. (1982).

Ribotyping. DNA $(2-5 \mu \mathrm{g})$ was cleaved by restriction endonuclease HindIII (40 $\mathrm{U} \mathrm{ml}^{-1}$; Boehringer Mannheim) and Pst $\mathrm{I}\left(50 \mathrm{U} \mathrm{ml}^{-1}\right.$; Gibco-BRL) at $37^{\circ} \mathrm{C}$ for $4 \mathrm{~h}$, according to the manufacturers' intructions. Restriction fragments were separated by horizontal gel electrophoresis in $0.8 \%$ 
Table 1. Strains of the Streptococcus bovis/Streptococcus equinus complex used in the study

\begin{tabular}{|c|c|c|}
\hline Strain designation & Former identification and designation(s)* & Source \\
\hline \multicolumn{3}{|c|}{ S. infantarius subsp. infantarius } \\
\hline HDP $90056^{\mathrm{T}}$ & S. infantarius, S. bovis, group 4, NCDO 599 & Infant's faeces \\
\hline HDP 90104 & S. infantarius & Dairy product \\
\hline HDP 90247 & S. infantarius, S. bovis, group 4, NCDO 2602 & Frozen peas \\
\hline HDP 91257 & & Endocarditis \\
\hline HDP 97027 & S. bovis biotype II.1, API 92.03 .336 & From human \\
\hline HDP 97029 & S. bovis biotype II.1, API 88.12.012 & Human blood \\
\hline HDP 98032 & & Human blood \\
\hline \multicolumn{3}{|c|}{ S. infantarius subsp. coli } \\
\hline HDP 90062 & & Medical case \\
\hline HDP 90246 & S. bovis biotype II.1, group 4, NCDO 964 & Unknown source \\
\hline HDP 90248 & S. bovis biotype II.1, group 4, NCDO 2620 & Infant's faeces \\
\hline HDP 90249 & S. bovis biotype II.1, group 4, NCDO 2632 & Medical case \\
\hline HDP 90256 & & Endocarditis \\
\hline HDP 91356 & & Endocarditis \\
\hline HDP 97028 & S. bovis biotype II.1, API 82.10 .072 & Human urinary tract infection \\
\hline HDP 97317 & S. bovis biotype II.1, NCDO 1600 & From human \\
\hline HDP 97318 & S. bovis biotype II.1, NCDO 1610 & Infant's faeces \\
\hline HDP 97319 & S. bovis biotype II.1, NCDO 1616 & From human \\
\hline HDP 97322 & S. bovis biotype II.1, NCDO 2759 & Human blood \\
\hline \multicolumn{3}{|l|}{ S. equinus } \\
\hline HDP $89506^{\mathrm{T}}$ & S. equinus, group $1, \mathrm{NCDO} 1037^{\mathrm{T}}$, CIP $102504^{\mathrm{T}}$ & Horse faeces \\
\hline \multicolumn{3}{|c|}{ S. bovis biotype II.1 } \\
\hline HDP $89505^{\mathrm{T}}$ & S. bovis, group 1 , NCDO $597^{\mathrm{T}}$, CIP $102302^{\mathrm{T}}$ & Cow faeces \\
\hline HDP 90083 & S. bovis biotype II.1, API 86.06 .003 & Unknown source \\
\hline \multicolumn{3}{|c|}{ S. bovis biotype II.2 } \\
\hline HDP 90084 & S. bovis, API 79.04.159 & Human vaginal discharge \\
\hline HDP 90382 & & Human urinary tract infection \\
\hline HDP 91130 & & Endocarditis \\
\hline HDP 91303 & & Endocarditis \\
\hline HDP 91317 & & Endocarditis \\
\hline HDP 91321 & & Endocarditis \\
\hline HDP 91333 & & Endocarditis \\
\hline HDP 91338 & & Endocarditis \\
\hline HDP 97320 & S. bovis, NCDO 2756 & From human \\
\hline HDP 97321 & S. bovis, NCDO 2758 & Human blood \\
\hline HDP 97323 & S. bovis, NCDO 2760 & Human blood \\
\hline HDP 97324 & S. bovis, NCDO 2761 & Human blood \\
\hline \multicolumn{3}{|c|}{ Genomic group 3} \\
\hline HDP 90058 & S. bovis, group 3, NCDO 2127, CIP 103245 & Mastitis \\
\hline \multicolumn{3}{|c|}{ S. gallolyticus (formerly S. bovis, biotype I) } \\
\hline HDP $98035^{\mathrm{T}}$ & S. gallolyticus, ACM $36.11^{\mathrm{T}}$, CIP $105428^{\mathrm{T}}$ & Koala faeces \\
\hline HDP 90055 & S. bovis, group 2, NCDO 2019 & Bovine mastitis \\
\hline HDP 90299 & S. bovis biotype I, API 84.03.028 & Unknown source \\
\hline \multicolumn{3}{|l|}{ S. alactolyticus } \\
\hline HDP $90057^{\mathrm{T}}$ & S. alactolyticus, group 6, NCDO $1091^{\mathrm{T}}$ & Pig intestine \\
\hline \multicolumn{3}{|l|}{ S. macedonicus } \\
\hline HDP $98362^{\mathrm{T}}$ & S. macedonicus, LMG $18488^{\mathrm{T}}$, CIP $105683^{\mathrm{T}}$ & Greek cheese \\
\hline \multicolumn{3}{|c|}{ E. saccharolyticus } \\
\hline HDP $90059^{\mathrm{T}}$ & E. saccharolyticus, group 5, NCDO $2594^{\mathrm{T}}$ & Straw bedding \\
\hline
\end{tabular}

* DNA homology groups are designated according to Farrow et al. (1984). 
Table 2. Biochemical characterization of species belonging to the $S$. bovis/S. equinus complex (no. of positive strains for each reaction)

Strains: 1, S. infantarius subsp. infantarius; 2, S. infantarius subsp. coli; 3, S. bovis biotype II.1; 4, S. equinus (type strain); 5, S. bovis biotype II.2; 6, S. gallolyticus; 7, genomic group 3; 8, S. alactolyticus (type strain); 9, S. macedonicus (type strain); 10, Enterococcus saccharolyticus (type strain). Enzymic activities and carbohydrate assimilation were determined using the API 20 STREP and Rapid ID32 STREP products. Readings were taken at $4 \mathrm{~h}$ and after overnight incubation. All strains produced acid from maltose and sucrose; acid was not produced from L-arabinose or ribose. All strains were leucine arylamidase-positive, and arginine dihydrolaseand pyrrolidonyl-arylamidase-negative.

\begin{tabular}{|lrrrrrrrrrr|}
\hline Characteristics & $\mathbf{1}$ & $\mathbf{2}$ & $\mathbf{3}$ & $\mathbf{4}$ & $\mathbf{5}$ & $\mathbf{6}$ & $\mathbf{7}$ & $\mathbf{8}$ & $\mathbf{9}$ & $\mathbf{1 0}$ \\
\hline No. of strains tested & 7 & 11 & 2 & 1 & 12 & 3 & 1 & 1 & 1 & 1 \\
Hydrolysis of: & & & & & & & & & & \\
$\quad$ Aesculin & 2 & 11 & 2 & 1 & 12 & 3 & 1 & 1 & 0 & 1 \\
Hippurate & 0 & 0 & 0 & 0 & 0 & 0 & 1 & 0 & 0 & 0 \\
$\quad$ Urea & 0 & 0 & 0 & 0 & 0 & 0 & 0 & 1 & 0 & 0 \\
Production of: & & & & & & & & & & \\
$\quad$ Acetoin & 7 & 11 & 2 & 1 & 12 & 3 & 0 & 1 & 1 & 0 \\
APPA* & 7 & 11 & 2 & 1 & 12 & 3 & 1 & 1 & 1 & 0 \\
$\alpha$-Galactosidase & 7 & 10 & 2 & 0 & 8 & 3 & 0 & 1 & 0 & 1 \\
$\beta$-Galactosidase & 0 & 0 & 0 & 0 & 12 & 0 & 1 & 0 & 1 & 0 \\
$\beta$-Glucosidase & 2 & 11 & 2 & 1 & 12 & 3 & 1 & 1 & 0 & 1 \\
$\beta$-Glucuronidase & 0 & 0 & 0 & 0 & 12 & 0 & 0 & 0 & 0 & 0 \\
$N$-Acetyl $\beta$-glucosaminidase & 0 & 0 & 0 & 0 & 1 & 0 & 0 & 0 & 0 & 1 \\
GTA† & 0 & 0 & 0 & 0 & 0 & 0 & 1 & 0 & 0 & 1 \\
$\beta$-Mannosidase & 0 & 0 & 0 & 0 & 12 & 2 & 0 & 0 & 0 & 0 \\
Production of acid from: & & & & & & & & & & \\
D-Arabitol & 0 & 0 & 0 & 0 & 0 & 0 & 0 & 0 & 0 & 1 \\
Cyclodextrin & 0 & 0 & 0 & 0 & 0 & 0 & 1 & 0 & 0 & 1 \\
Glycogen & 6 & 0 & 2 & 0 & 0 & 3 & 1 & 0 & 0 & 0 \\
Inulin & 0 & 0 & 2 & 0 & 0 & 3 & 1 & 0 & 0 & 1 \\
Lactose & 6 & 11 & 2 & 0 & 12 & 3 & 1 & 0 & 1 & 1 \\
D-Mannitol & 0 & 0 & 0 & 0 & 0 & 3 & 1 & 1 & 0 & 1 \\
Melezitose & 0 & 0 & 0 & 0 & 6 & 0 & 0 & 0 & 0 & 1 \\
Melibiose & 5 & 0 & 2 & 0 & 2 & 0 & 0 & 0 & 0 & 1 \\
Methyl $\beta$-D-glucopyranoside & 2 & 11 & 2 & 0 & 12 & 3 & 1 & 1 & 0 & 0 \\
Pullulan & 6 & 0 & 0 & 0 & 0 & 3 & 1 & 0 & 0 & 0 \\
D-Raffinose & 5 & 5 & 2 & 0 & 8 & 2 & 1 & 0 & 0 & 1 \\
Sorbitol & 0 & 0 & 0 & 0 & 0 & 0 & 0 & 0 & 0 & 1 \\
D-Tagatose & 0 & 0 & 0 & 0 & 3 & 0 & 1 & 0 & 0 & 0 \\
Trehalose & 0 & 0 & 0 & 1 & 12 & 3 & 1 & 0 & 0 & 1 \\
Starch & 7 & 4 & 2 & 0 & 0 & 3 & 1 & 0 & 1 & 1 \\
\hline
\end{tabular}

* APPA, Alanyl-phenylalanyl-proline arylamidase.

$\dagger$ GTA, Glycyl-tryptophan arylamidase.

(w/v) agarose gel (Appligene) in TBE buffer (0.089 M Tris, $0.089 \mathrm{M}$ boric acid, 0.025 $\mathrm{M} \mathrm{Na}_{2}$ EDTA, $\mathrm{pH}$ 8) for $16 \mathrm{~h}$ at $1.5 \mathrm{~V} \mathrm{~cm}^{-1}$. DNA fragments were blotted on to a positively charged nylon membrane (Hybond-N; Amersham) using a VacuGene vacuum-transfer system (Pharmacia Biotech). Hybridization with five specific digoxigenin-labelled oligonucleotides (28 pmol each) was conducted as previously described (Régnault et al., 1997) and according to the instructions provided with the DIG Easy Hyb kit (Boehringer Mannheim). Bound digoxigenin was detected using an alkaline-phosphatase-conjugated anti-digoxigenin antibody and a mixture of nitroblue tetrazolium and 5-bromo-4- chloro-3-indolylphosphate as the enzyme substrate (all chemicals were from Sigma) (Machado et al., 1998; Régnault et al., 1997). Membranes were scanned and the sizes of DNA fragments calculated using the Taxotron package (Institut Pasteur) as described elsewhere (Machado et al., 1998). DNA extracted from Citrobacter koseri CIP 105177 and cleaved with $M l u \mathrm{I}\left(2 \mathrm{U} \mathrm{ml}^{-1}\right)$ was used as the external standard (Grimont \& Grimont, 1986; Machado et al., 1998).

Quantitative DNA-DNA hybridization. DNA from $S$. bovis HDP $89505^{\mathrm{T}}$ and $S$. infantarius HDP 90104 and HDP 90246 was labelled in vitro with $\left[{ }^{3} \mathrm{H}\right]$ adenine triphosphate, $\left[{ }^{3} \mathrm{H}\right]-$ thymidine triphosphate, $\left[{ }^{3} \mathrm{H}\right]$ guanosine triphosphate and 


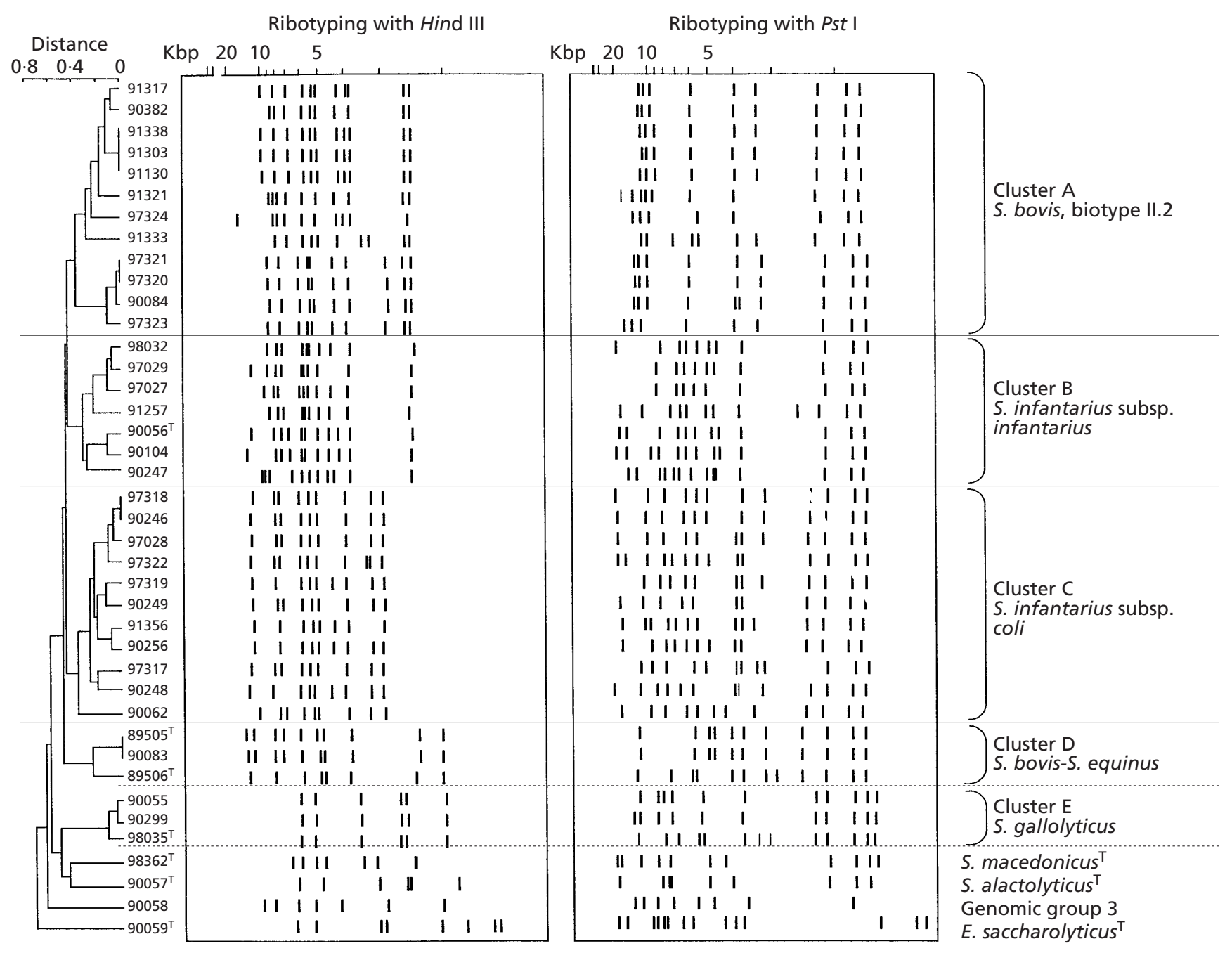

Fig. 1. Normalized graph of the rRNA gene restriction patterns obtained after digestion with HindIII and Pstl. (Fragment size values were determined using Citrobacter koseri CIP 105177 digested with Mlul as the molecular mass standard.) A dendrogram was derived from the mean linkage analysis of the restriction patterns. Letters indicate clusters, as discussed in the text.

$\left[{ }^{3} \mathrm{H}\right]$ cytosine triphosphate using a Megaprim DNA-labelling reaction kit (all from Amersham). DNA-DNA hybridizations were performed in stringent conditions at $60{ }^{\circ} \mathrm{C}$ for $16 \mathrm{~h}$ according to the $\mathrm{S} 1$ nuclease/trichloracetic acid precipitation method of Crosa et al. (1973), with minor modifications (Grimont et al., 1980). The temperature $\left(T_{\mathrm{m}}\right)$ at which $50 \%$ of the reassociated DNA became hydrolysable by the $\mathrm{S} 1$ nuclease was determined (Grimont et al., 1980) and the differences $\left(\Delta T_{\mathrm{m}}\right)$ between the melting temperatures of homoduplexes and heteroduplexes were calculated in order to estimate DNA divergence between strains with high levels of DNA homology.

16S rRNA sequence determination and analysis. PCR of $16 \mathrm{~S}$ rRNA encoding DNA and sequencing of amplified fragments were performed as described previously (Janvier \& Grimont, 1995). Alignment with the available streptococcal sequence from GenBank and phylogenetic analysis of the 16S rRNA data were performed with the MEGALIGN program from the DNASTAR package.

\section{RESULTS}

\section{Phenotypic characterization}

All streptococcal strains shared common characteristics of morphology and growth. They were Grampositive, non-motile, non-sporulating and catalasenegative cocci occurring in pairs or short chains. Their growth in buffer dextrose and in brain-heart infusion broths was homogeneous. They grew in MRS broth without gas production and they did not grow in $6.5 \%$ (w/v) $\mathrm{NaCl}$ broth. E. saccharolyticus strain HDP $90059^{\mathrm{T}}$ yielded similar characteristics, but grew in $6.5 \%(\mathrm{w} / \mathrm{v}) \mathrm{NaCl}$ broth and on bile/aesculin agar. All of the strains except the reference strain of genomic group 3 and the type strain of E. saccharolyticus were positive for the Voges-Proskauer test. The strains formerly called $S$. bovis produced leucine aminopeptidase, alanyl-phenylalanyl-proline arylamidase 
Table 3. Quantitative hybridization with labelled DNA from strains

ND, Not determined.

\begin{tabular}{|c|c|c|c|c|c|}
\hline \multirow[t]{2}{*}{ Ribotyping cluster and strain no. } & \multicolumn{2}{|c|}{ HDP 90104} & \multicolumn{2}{|c|}{ HDP 90246} & \multirow{2}{*}{$\begin{array}{c}\text { HDP 89505 } \\
\%\end{array}$} \\
\hline & $\%$ & $\Delta T_{\mathrm{m}}$ & $\%$ & $\Delta T_{\mathrm{m}}$ & \\
\hline \multicolumn{6}{|l|}{$\begin{array}{l}\text { Cluster B, S. infantarius subsp. } \\
\text { infantarius }\end{array}$} \\
\hline HDP 90104 & 100 & 0 & 67 & 3 & 47 \\
\hline HDP $90056^{T}$ & 79 & 2 & 60 & 3 & 39 \\
\hline HDP 90247 & 77 & 0 & 66 & 4 & 40 \\
\hline HDP 91257 & 77 & 1 & 65 & 3 & 40 \\
\hline HDP 97027 & 80 & 2 & 68 & 5 & 40 \\
\hline HDP 97029 & 82 & 1 & 62 & 4 & 43 \\
\hline HDP 98032 & 70 & 0 & 60 & 6 & 38 \\
\hline \multicolumn{6}{|l|}{ Cluster C, S. infantarius subsp. coli } \\
\hline HDP 90246 & 64 & 1 & 100 & 0 & 42 \\
\hline HDP 90062 & 64 & 3 & 88 & 2 & 48 \\
\hline HDP 90248 & 56 & 4 & 90 & ND & 46 \\
\hline HDP 90249 & 69 & 2 & 94 & 1 & 49 \\
\hline HDP 91356 & 57 & $\mathrm{ND}$ & 90 & ND & 43 \\
\hline HDP 97028 & 55 & 2 & 83 & 0 & 41 \\
\hline HDP 97317 & 69 & 1 & 93 & ND & 50 \\
\hline HDP 97318 & 63 & ND & 100 & ND & 47 \\
\hline \multicolumn{6}{|l|}{ Cluster D, S. bovis and S. equinus } \\
\hline HDP $89505^{\mathrm{T}}$ & 33 & ND & 46 & ND & 100 \\
\hline HDP $89506^{\mathrm{T}}$ & 42 & ND & 45 & ND & 71 \\
\hline HDP 90083 & 42 & $\mathrm{ND}$ & 46 & ND & 75 \\
\hline \multicolumn{6}{|l|}{ Cluster A, S. bovis biotype II.2 } \\
\hline HDP 90084 & 29 & $\mathrm{ND}$ & 37 & ND & 30 \\
\hline HDP 91303 & 29 & $\mathrm{ND}$ & 37 & ND & 30 \\
\hline HDP 91317 & 28 & ND & 33 & ND & 50 \\
\hline HDP 91323 & 28 & ND & 39 & ND & 31 \\
\hline \multicolumn{6}{|l|}{ Cluster E, S. gallolyticus } \\
\hline HDP $98035^{\mathrm{T}}$ & 32 & ND & 38 & ND & 33 \\
\hline HDP 90055 & 33 & ND & 33 & ND & 41 \\
\hline HDP 90299 & 42 & ND & 26 & ND & 43 \\
\hline \multicolumn{6}{|l|}{ Other strains tested } \\
\hline HDP $98362^{\mathrm{T}}$, S. macedonicus & 30 & $\mathrm{ND}$ & 34 & ND & 53 \\
\hline HDP $90057^{\mathrm{T}}, S$. alactolyticus & 15 & ND & 23 & ND & 21 \\
\hline HDP 90058, genomic group 3 & 2 & $\mathrm{ND}$ & 4 & $\mathrm{ND}$ & 5 \\
\hline HDP $90059^{\mathrm{T}}$, E. saccharolyticus & 2 & ND & 3 & ND & 5 \\
\hline
\end{tabular}

and $\alpha$-galactosidase. They did not produce arginine dihydrolase or pyrrolidonyl arylamidase. The biochemical characteristics of $S$. infantarius strains were similar to those of the other strains of $S$. bovis of biotype II.1 including the type strain of $S$. bovis. Eight strains out of 18 reacted with the group D antiserum. They differ by the lack of fermentation of inulin and by the variation of some characteristics, such as the hydrolysis of aesculin, the production of $\beta$-glucosidase and the fermentation of melibiose, pullulan, raffinose and starch (Table 2). The absence of the production of $\beta$-galactosidase and $\beta$-mannosidase and the lack of acidification of trehalose allowed the delineation of $S$. infantarius and $S$. bovis biotype II.2. Other biochemical tests that differentiate this species from repesentative strains of $S$. equinus, $S$. gallolyticus, DNA homology group $3, S$. alactolyticus, $S$. macedonicus and $E$. saccharolyticus are shown in Table 2.

The two subgroups of S. infantarius differed in terms of the presence or absence of some characteristics, such as the hydrolysis of aesculin, the presence of $\beta$-glucosidase and the acidification of starch, glycogen, melibiose, methyl $\beta$-D-glucopyranoside and pullulan (Table 2). The strains of the first subgroup, except strains HDP 97027 and HDP 91257, fail to hydrolyse aesculin and to produce $\beta$-glucosidase. Most strains produce acid from glycogen, pullulan and melibiose. 
Conversely, all of the strains of the second subgroup were aesculin- and $\beta$-glucosidase-positive. None of them produced acid from glycogen, pullulan or melibiose.

\section{Ribotyping}

The patterns of rRNA gene restriction analysis after digestion with HindIII and PstI are shown in Fig. 1. Mean linkage statistical analysis of the size of DNA fragments delineated five clusters of strains which were designated A to E. Statistical analysis of restriction patterns using two other clustering methods (singlelinkage and unweighted pair group method with arithmetic averages) displayed similar results. Cluster A contained all of the strains identified as $S$. bovis biotype II.2. Cluster B contained the seven strains of the first subgroup of $S$. infantarius, i.e. three strains that were previously designated $S$. infantarius and four additional isolates. A second subgroup of $S$. infantarius, designated as cluster $\mathrm{C}$, comprised 11 strains, which had been identified as $S$. bovis biotype II.1. Cluster D contained the type strain of $S$. equinus and two strains identified as $S$. bovis biotype II.1, including the type strain of $S$. bovis. Cluster E corresponded to $S$. gallolyticus. The four additional isolates tested (which are the type strains of $S$. alactolyticus, S. macedonicus and E. saccharolyticus) and the reference strain of DNA homology group 3 are distant from the former clusters.

\section{DNA-DNA hybridization}

The results obtained in hybridization experiments with radiolabelled DNA from HDP 90104 (S. infantarius, cluster B), HDP 90246 (S. infantarius, cluster C) and HDP $89505^{\mathrm{T}}$ (S. bovis, cluster D) are shown in Table 3. High levels of homology were found between DNA of strains belonging to the same cluster, $\mathrm{B}, \mathrm{C}$ or $\mathrm{D}$ (i.e. $70-100 \%$ and $\Delta T_{\mathrm{m}}<3{ }^{\circ} \mathrm{C}$ ). The close relationship between ribogroups $\mathrm{B}$ and $\mathrm{C}$ was confirmed by the results of DNA-DNA hybridization assays with radiolabelled DNA from $S$. infantarius strains HDP 90104 and HDP 90246. Moreover, low hybridization levels (26-50\%) were observed between strains of clusters B and $\mathrm{C}$ and strains belonging to clusters $\mathrm{A}, \mathrm{D}$ and $\mathrm{E}$. The reference strains of the other species of the $S$. bovis/S. equinus complex including the type strains of $S$. alactolyticus, $S$. macedonicus and $E$. saccharolyticus and DNA homology group 3 yielded low homology with both HDP 90104 and HDP 90246 (2-34\%).

\section{S rRNA gene sequencing}

Comparative analysis of the determined sequence for $S$. infantarius HDP 90104 confirmed the inclusion of this species in the genus Streptococcus (sequence similarity between 89 and $99 \%$ with the other type strains of described species in the genus). The closest relations were $S$. bovis $(98 \cdot 2 \%)$, S. macedonicus
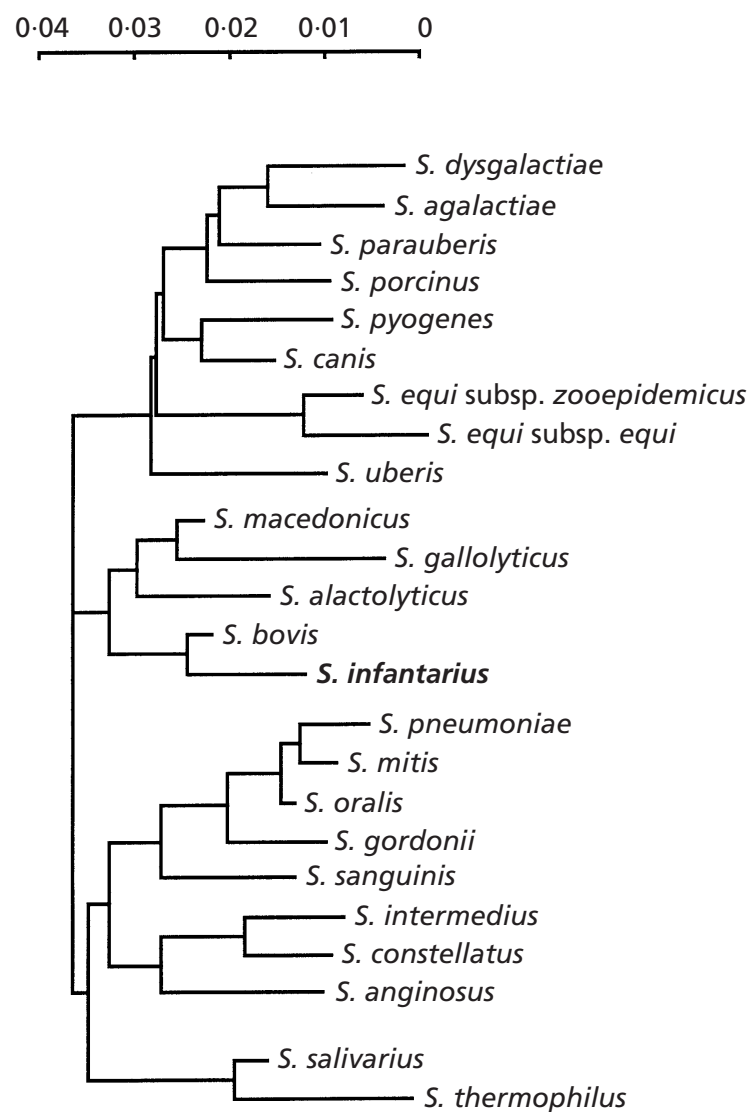

Fig. 2. Unrooted phylogenetic tree of Streptococcus infantarius strain HDP 90104 and other major streptococcal species (using sequences available from GenBank) based on comparative analysis of the 16S rRNA gene sequences. The dendrogram was generated by using the neighbour-joining algorithm. Bar, evolutionary distance value $\left(K_{\text {nuc }}\right)$ between sequences.

$(97 \cdot 9 \%)$ and S. gallolyticus $(95 \cdot 8 \%)$, as shown in Fig. 2.

\section{DISCUSSION}

The comparison of phenotypic and genotypic characteristics of group D streptococcal strains, mostly of human origin, confirms the heterogeneity of the $S$. bovis/S. equinus complex and the description of a new species called $S$. infantarius. In addition, analysis of 18 strains of $S$. infantarius allows the delineation of two different subspecies.

Using ribotyping, we have demonstrated that, among the mannitol-negative strains, the strains formerly designated as $S$. bovis biotype II.1 can be separated into two different clusters (B and C) associated with different biochemical properties. Their ribotypes were distinct from those of cluster D (which includes the type strains of $S$. bovis and S. equinus), cluster A (S. bovis biotype II.2) and other group D streptococcal species. The determination of rRNA gene restriction patterns has been shown to be a general method for 
Table 4. Characteristics useful for the differentiation of $S$. infantarius from $S$. bovis and major species belonging to the $S$. bovis/S. equinus complex [description based on results obtained with strains in this study and data from Farrow et al. (1984), Knight \& Shlaes (1985), Nelms et al. (1995), Osawa et al. (1995) and Tsakalidou et al. (1998)].

Strains: 1, S. infantarius subsp. infantarius; 2, S. infantarius subsp. coli; 3, S. bovis biotype II.1; 4, S. equinus; 5, S. bovis biotype II.2; 6, S. gallolyticus; 7, S. macedonicus. +, More than $85 \%$ of the strains positive; - , less than $15 \%$ of the strains positive; $\mathrm{v}, 15-85 \%$ of the strains positive; $\mathrm{X}$, not designated.

\begin{tabular}{|lccccccc|}
\hline Characteristics & $\mathbf{1}$ & $\mathbf{2}$ & $\mathbf{3}$ & $\mathbf{4}$ & $\mathbf{5}$ & $\mathbf{6}$ & $\mathbf{7}$ \\
\hline $\begin{array}{l}\text { Hydrolysis of aesculin } \\
\text { Production of: }\end{array}$ & $\mathrm{V}$ & + & + & + & + & + & - \\
$\quad \alpha$-Galactosidase & & & & & & & \\
$\beta$-Galactosidase & + & + & + & - & $\mathrm{V}$ & + & - \\
$\beta$-Glucosidase & - & - & - & $\mathrm{V}$ & + & - & - \\
$\beta$-Glucuronidase & $\mathrm{V}$ & + & + & + & + & + & - \\
$\beta$-Mannosidase & - & - & - & - & + & - & - \\
Production of acid from & - & - & - & - & + & $\mathrm{V}$ & - \\
$\quad$ Glycogen & & & & & & & \\
Inulin & + & - & + & - & - & + & - \\
Lactose & - & - & + & $\mathrm{V}$ & - & + & - \\
D-Mannitol & + & + & + & - & + & + & + \\
Melibiose & - & - & - & - & - & + & - \\
$\quad$ Methyl $\beta$-D-glucopyranoside & $\mathrm{V}$ & + & + & $\mathrm{V}$ & + & + & $\mathrm{V}$ \\
$\quad$ Pullulan & + & - & - & - & - & + & - \\
Trehalose & - & - & - & + & + & + & - \\
Starch & + & $\mathrm{V}$ & + & - & - & + & + \\
Cluster (ribotyping) & $\mathrm{B}$ & $\mathrm{C}$ & $\mathrm{D}$ & $\mathrm{D}$ & $\mathrm{A}$ & $\mathrm{E}$ & $\mathrm{X}$ \\
\hline
\end{tabular}

taxonomic analysis of bacteria (Grimont \& Grimont, 1986). This method is a powerful tool for species identification and also for distinguishing between subspecies or biotypes within species (Bouvet et al., 1991; Doit et al., 1994; Rudney \& Larson, 1994). The combination of patterns obtained with two different restriction enzymes may generate more diversity between isolates and strengthen the results of the cluster analysis (Grimont \& Grimont, 1986; Machado et al., 1998). Cluster B includes $S$. infantarius HDP 90104 and six other strains which were mostly $\beta$-glucosidasenegative, whereas cluster $\mathrm{C}$ comprises closely related $\beta$-glucosidase- and aesculin-positive $S$. bovis biotype II.1 strains. The genetic relatedness, evaluated by the level of hybridization and the difference in melting temperature, was superior between strains belonging to the same cluster (i.e. B or C) than between strains from the two clusters. Since the difference did not meet the requirement of the Ad Hoc Committee and did not allow the distinction of two different species (Wayne et al., 1987), we propose the delineation of two subspecies. Ribotyping analysis demonstrated also that these two clusters are distinct from cluster D, which includes the type strains of $S$. bovis and S. equinus. The similarity of the restriction patterns of these two type strains and their quantitative DNA-DNA hybridization are consistent with the levels previously reported (Farrow et al., 1984; Kilpper-Bälz et al., 1982; Nelms et al., 1995). Moreover, our results confirm the lack of homology between strains of cluster A ( $S$. bovis, biotype II.2), cluster E ( $S$. gallolyticus, formerly $S$. bovis biotype I) and the type strain of $S$. bovis (Coykendall \& Gustafson, 1985; Farrow et al., 1984; Garvie \& Bramley, 1979). In addition, the strains identified as $S$. bovis biotype II.2 belong to a distinct cluster (A). This delineation is in accordance with previous observations on a limited number of strains (Coykendall \& Gustafson, 1985; Garvie \& Bramley, 1979 ) and is under investigation in our laboratory. $S$. gallolyticus, $S$. alactolyticus and E. saccharolyticus appeared distantly related to $S$. infantarius and $S$. bovis or $S$. equinus according to ribotyping and DNA hybridization assays. S. macedonicus (Tsakalidou et al., 1998) has been described recently as an aesculinnegative species belonging to the $S$. bovis/S. equinus complex. However, a reduced 16S rRNA similarity $(97.9 \%)$ and a low level of DNA-DNA hybridization $(30-34 \%)$ warranted the separation of this species from $S$. infantarius.

Results of ribotyping, DNA-DNA hybridization assays and $16 \mathrm{~S}$ rRNA sequence analysis confirm the inclusion of $S$. infantarius within the $S$. bovis/S. equinus complex and its distinction from previously described species. The comparative analysis of the strains confirms the presence of two distinct subspecies for which the names $S$. infantarius subsp. infantarius $(\beta$ glucosidase- and aesculin-variable) and $S$. infantarius subsp. coli (aesculin- and $\beta$-glucosidase-positive) are proposed.

\section{Description of Streptococcus infantarius sp. nov.}

Streptococcus infantarius (in.fan.ta'ri.us. L. adj. infantarius relating to infants, the source of the type strain).

The cells are Gram-positive cocci that occur in pairs or short chains and are non-motile, non-sporulating and catalase-negative. Colonies on blood agar are circular, $1 \mathrm{~mm}$ in diameter after a $24 \mathrm{~h}$ incubation at $37^{\circ} \mathrm{C}$, unpigmented and $\alpha$-haemolytic. Growth is enhanced in a $5 \% \mathrm{CO}_{2}$ atmosphere. Strains show homogeneous growth in buffer dextrose and in brain-heart infusion broths. Growth also occurs in MRS broth, without gas production. No growth in $6.5 \%(\mathrm{w} / \mathrm{v}) \mathrm{NaCl}$ broth. No exopolysaccharide production on $5 \%$ sucrose medium. The Lancefield group D antigen is present in $40 \%$ of the strains. Strains are positive for VogesProskauer, leucine aminopeptidase and alanylphenylalanyl-proline arylamidase tests. Arginine dihydrolase, alkaline phosphatase and pyrrolidonylarylamidase tests are negative. Urea and hippurate are not hydrolysed. Aesculin hydrolysis is variable. Nearly all strains are $\alpha$-galactosidase-positive. They are $N$ acetyl- $\beta$-glucosaminidase-, $\beta$-galactosidase-, $\beta$-glucuronidase-, glycyl-tryptophan arylamidase- and $\beta$ - 
mannosidase-negative. All strains produce acid from lactose, maltose and sucrose. They do not produce acid from arabinose, arabitol, cyclodextrine, inulin, D-mannitol, melezitose, ribose, sorbitol, D-tagatose or trehalose. Variable results occur with glycogen, melibiose, methyl $\beta$-D-glucopyranoside, pullulan, Draffinose and starch. Characteristics useful in their differentiation from related organisms and also in the delineation between the two subspecies are listed in Table 4.

Most of the $S$. infantarius subsp. infantarius strains do not hydrolyse aesculin (five out of seven) and are $\beta$-glucosidase- and methyl $\beta$-D-glucopyranoside-negative. They produce acid from glycogen, melibiose, pullulan and starch, with some exceptions. The type strain of $S$. infantarius subsp. infantarius HDP $90056^{\mathrm{T}}$ $\left(=\mathrm{NCDO} 599^{\mathrm{T}}\right)$ is aesculin- and $\beta$-glucosidase-negative. It produces acid from glycogen, pullulan, Draffinose and starch, but not from melibiose or methyl $\beta$-D-glucopyranoside. The type strain was isolated from the faeces of an infant human. Other isolates have been obtained from clinical specimens (three from blood, including one from a case of endocarditis) or food products (a dairy product and frozen peas). $S$. infantarius subsp. coli is $\beta$-glucosidase- and aesculinpositive. Glycogen, starch, melibiose and pullulan are not fermented. Ten strains of this subspecies were isolated from human specimens including faeces from two infants, urine (one isolate) and blood (three isolates, including one from a case of endocarditis). The reference strain for this subspecies is HDP 90246 $(=$ NCDO 964).

\section{REFERENCES}

Bentley, R. W. \& Leigh, J. A. (1995). Development of PCR-based hybridization protocol for identification of streptococcal species. J Clin Microbiol 33, 1296-1301.

Bentley, R. W., Leigh, J. A. \& Collins, M. D. (1991). Intrageneric structure of Streptococcus based on comparative analysis of small-subunit rRNA sequences. Int J Syst Bacteriol 41, 487-494.

Bouvet, A., Grimont, F. \& Grimont, P. A. D. (1991). Intraspecies variations in nutritionally variant streptococci: rRNA gene restriction patterns of Streptococcus defectivus and Streptococcus adjacens. Int J Syst Bacteriol 41, 483-486.

Bouvet, A., Grimont, F., Collins, M. D., Benaoudia, F., Devine, C., Régnault, B. \& Grimont, P. A. D. (1997). Streptococcus infantarius sp. nov. related to $S$. bovis and S. equinus. Adv Exp Med Biol 418, 393-395.

Brenner, D. J., McWhorter, A. C., Knutson, J. K. \& Steigerwalt, A. G. (1982). Escherichia vulneris: a new species of Enterobacteriaceae associated with human wounds. J Clin Microbiol 15, 1133-1140.

Bridge, P. D. \& Sneath, P. H. A. (1983). Numerical taxonomy of Streptococcus. J Gen Microbiol 129, 565-597.

Coykendall, A. L. \& Gustafson, K. B. (1985). Deoxyribonucleic acid hybridizations among strains of Streptococcus salivarius and Streptococcus bovis. Int J Syst Bacteriol 35, 274-280.

Crosa, J. H., Brenner, D. J. \& Falkow, S. (1973). Use of a singlestrand specific nuclease for analysis of bacterial and plasmid deoxyribonucleic acid homo- and heteroduplexes. J Bacteriol 115, 904-911.
Doit, C., Grimont, F., Whiley, R. A., Régnault, B., Grimont, P. A. D., Hardie, J. M. \& Bouvet, A. (1994). Ribotypes of the 'Streptococcus milleri'-group allow discrimination between strains of Streptococcus constellatus, Streptococcus intermedius and Streptococcus anginosus. In Pathogenic Streptococci, Present and Future, pp. 531-532. Edited by A. Totolian. St Petersburg: Lancer.

Edberg, S. C., Trepeta, R. W., Kontnick, C. M. \& Torres, A. R. (1985). Measurement of active constitutive $\beta$-D-glucosidase (esculinase) in the presence of sodium desoxycholate. $J$ Clin Microbiol 21, 363-365.

Facklam, R. R. (1972). Recognition of group D streptococcal species of human origin by biochemical and physiological tests. Appl Microbiol 23, 1131-1139.

Facklam, R. R., Rhoden, D. L. \& Smith, P. B. (1984). Evaluation of the rapid Strep system for identification of clinical isolates of Streptococcus species. J Clin Microbiol 20, 894-898.

Farrow, J. A. E., Kruze, J., Phillips, B. A., Bramley, A. J. \& Collins, M. D. (1984). Taxonomic studies on Streptococcus bovis and Streptococcus equinus: description of Streptococcus alactolyticus sp. nov. and Streptococcus saccharolyticus sp. nov. Syst Appl Microbiol 5, 467-482.

Freney, J., Bland, S., Etienne, J., Desmonceaux, M., Boeufgras, J. M. \& Fleurette, J. (1992). Description and evaluation of the semi-automated 4-hour rapid ID 32 strep method for identification of streptococci and members of related genera. J Clin Microbiol 30, 2657-2661.

Garvie, E. I. \& Bramley, A. J. (1979). Streptococcus bovis - an approach to its classification and its importance as a cause of bovine mastitis. J Appl Bacteriol 46, 557-566.

Garvie, E. I. \& Farrow, J. A. E. (1981). Sub-divisions within the genus Streptococcus using deoxyribonucleic acid/ribosomal ribonucleic acid hybridization. Zbl Bakt Hyg I Abt Orig C2, 299-310.

Grimont, F. \& Grimont, P. A. D. (1986). Ribosomal ribonucleic acid gene restriction patterns as potential taxonomic tools. Ann Inst Pasteur/Microbiol 137B, 165-175.

Grimont, F. \& Grimont, P. A. D. (1995). Determination of rRNA gene restriction patterns. In Diagnostic Bacteriology Protocols, pp. 149-164. Edited by J. Howard \& D. M. Withcombe. Totowa: Humana Press.

Grimont, P. A. D., Popoff, M. Y., Grimont, F., Coynault, C. \& Lemelin, M. (1980). Reproducibility and correlation study of three deoxyribonucleic acid hybridization procedures. Curr Microbiol 4, 325-330.

Hardie, J. M. (1986). Genus Streptococcus Rosenbach 1884. In Bergey's Manual of Systematic Bacteriology, vol. 2, pp. 1043-1071. Edited by P. H. A. Sneath, N. S. Mair \& M. E. Sharpe. Baltimore: Williams \& Wilkins.

Janvier, M. \& Grimont, P. A. D. (1995). The genus Methylophaga, a new line of descent within phylogenetic branch $\gamma$ of Proteobacteria. Res Microbiol 146, 543-550.

Jones, D., Sackin, M. J. \& Sneath, P. H. A. (1972). A numerical study of streptococci of serological group D. J Gen Microbiol 72, 439-450.

Kilpper-Bälz, R., Fischer, G. \& Schleifer, K. H. (1982). Nucleic acid hybridization of group $\mathrm{N}$ and group D streptococci. Curr Microbiol 7, 245-250.

Klein, R. S., Recco, R. A., Catalano, M. T., Edberg, S. C., Casey, J. I. \& Steigbigel, N. H. (1977). Association of Streptococcus bovis with carcinoma of the colon. $N$ Engl J Med 297, 800-802.

Knight, R. G. \& Shlaes, D. M. (1985). Physiological characteristics 
and deoxyribonucleic acid relatedness of human isolates of Streptococcus bovis and Streptococcus bovis (var.). Int J Syst Bacteriol 35, 357-361.

Machado, J., Grimont, F. \& Grimont, P. A. D. (1998). Computer identification of Escherichia coli rRNA gene restriction patterns. Res Microbiol 149, 119-135.

Nelms, L. F., Odelson, D. A., Whitehead, T. R. \& Hespell, R. B. (1995). Differentiation of ruminal and human Streptococcus bovis strains by DNA homology and 16S rRNA probes. Curr Microbiol 31, 294-300.

Osawa, R., Fujisawa, T. \& Sly, L. I. (1995). Streptococcus gallolyticus sp. nov.; gallate degrading organisms formerly assigned to Streptococcus bovis. Syst Appl Microbiol 18, 74-78.

Régnault, B., Grimont, F. \& Grimont, P. A. D. (1997). Universal ribotyping method using a chemically labelled oligonucleotide probe mixture. Res Microbiol 148, 649-659.

Rodriguez, U. \& Collins, M. D. (1990). Phylogenic analysis of Streptococcus saccharolyticus based on 16S rRNA sequencing. FEMS Microbiol Lett 71, 231-234.

Rudney, J. D. \& Larson, C. J. (1994). Use of restriction fragment polymorphism analysis of rRNA genes to assign species to unknown clinical isolates of oral viridans streptococci. $J$ Clin Microbiol 32, 437-443.

Ruoff, K. L., Ferraro, M. J., Holden, J. \& Kunz, L. J. (1984). Identification of Streptococcus bovis and Streptococcus salivarius in clinical laboratories. J Clin Microbiol 20, 223-226.

Ruoff, K. L., Miller, S. I., Garner, C. V., Ferraro, M. J. \& Calderwood, S. B. (1989). Bacteremia with Streptococcus bovis and Streptococcus salivarius: clinical correlates of more accurate identification of isolates. J Clin Microbiol 27, 305-308.

Schleifer, K. H. \& Kilpper-Bälz, R. (1984). Transfer of Streptococcus faecalis and Streptococcus faecium to the genus Enterococcus nom. rev. as Enterococcus faecalis comb. nov. and Enterococcus faecium comb. nov. Int J Syst Bacteriol 34, 31-34.

Tsakalidou, E., Zoidou, E., Pot, B., Wassill, L., Ludwig, W., Devriese, L. A., Kalantzopoulos, G., Schleifer, K. H. \& Kersters, K. (1998). Identification of streptococci from Greek Kasseri cheese and description of Streptococcus macedonicus sp. nov. Int J Syst Bacteriol 48, 519-527.

Wayne, L. G., Brenner, D. J., Colwell, R. R. \& 9 other authors (1987). International Committee on Systematic Bacteriology. Report of the ad hoc committee on reconciliation of approaches to bacterial systematics. Int J Syst Bacteriol 37, 463-464. 